\title{
Neural relapse in multibacillary leprosy 6 years after end of treatment
}

\author{
Recidiva Neural em hanseníase multibacilar após 6 anos de tratamento
}

\author{
Leandra Oliveira Teixeira ${ }^{1}$ \\ Hélcio Takeshi Akamatsu ${ }^{1}$ \\ Cleverson Teixeira Soares ${ }^{3}$
}

\author{
Carlos Maximiliano Gaspar Carvalho Heil Silva \\ Jaison Antônio Barreto ${ }^{2}$
}

\begin{abstract}
This article presents a case of relapse, with isolated neural manifestation, in a multibacillary patient previously treated with multidrug therapy for multibacillary leprosy ( 24 doses). The patient returned to the service six years after the end of treatment, with pain in hands and legs. He was investigated, and the serological monitoring showed an important increase in anti-phenolic glycolipid serum levels. A neural recurrence was suspected, since the patient had no new skin lesions. A new biopsy in the right ulnar nerve showed a bacilloscopy of $2+$, compatible with relapse. This is a literature review of the etiological, clinical, propedeutical and diagnostic aspects of this situation so poorly understood.

Keywords: Biopsy; Combined modality therapy; Leprosy, borderline; Recurrence; Serology; Ulnar nerve

Resumo: O presente artigo relata um caso de recidiva, com manifestação neural isolada, em paciente multibacilar previamente tratado com poliquimioterapia para multibacilar 24 doses. O paciente retorna ao serviço, seis anos depois do fim do tratamento, com dores em mãos e pernas. Na investigação, o acompanhamento da sorologia anti-glicolipídeo fenólico 1 demonstrou aumento importante dos níveis séricos, e foi aventada a hipótese de recidiva neural, já que o paciente não apresentava lesões cutâneas novas. Uma nova biópsia, em nervo ulnar direito, demonstrou baciloscopia de $2+$, compatível com recidiva. Faz-se revisão da literatura sobre aspectos etiológicos, clínicos, propedêuticos e diagnósticos dessa situação tão pouco compreendida.

Palavras-chave: Biópsia; Hanseníase dimorfa; Nervo ulnar; Recidiva; Sorologia; Terapia combinada
\end{abstract}

\section{INTRODUCTION}

A relapse of Hansen's disease should be considered when the patient, after having completed the adequate treatment and being discharged as cured, presents again with signs and symptoms of illness activity. ${ }^{1}$ The clinical manifestations, that usually occur after 5 years in average, may be cutaneous (new lesions, increase of preexisting lesions, erythema and infiltration, non traumatic lesion ulceration) and/or neural (thickening and/or hyperesthesia of nerves and trunks previously normal; paresis or paralysis of muscles that were not affected before, new anesthetic areas or exacerbation of sensibility alteration in previously affected areas). ${ }^{1,2} \mathrm{~A}$ differential diagnosis is required with reactions, which can be done by evaluating the clinical picture, the response to antireactional drugs - such as corticoids, for example - and the laboratory exams: serology for IgM anti-phenolic glycolipid 1 (PGL-1), bacilloscopy and histopathology. The

\footnotetext{
Received on 03.03.2011.

Approved by the Advisory Board and accepted for publication on 15.06.2011.

* Study carried out at the Instituto Lauro de Souza Lima (ILSL) - Bauru (SP), Brazil.

Conflict of interest: None / Conflito de interesse: Nenbum

Financial funding: None / Suporte financeiro: Nenhum

Resident in Dermatology at the Instituto Lauro de Souza Lima (ILSL) - Bauru (SP), Brazil.

Dermatologist, PhD in Dermatology by the Universidade de São Paulo Head of the Epidemiology Section of the Instituto Lauro de Souza Lima (ILSL) - Bauru (SP), Brazil.

Pathologist, PhD in Pathology by Universidade Estadual Paulista - Botucatu-SP, Head of the Pathological Anatomy Section of the Instituto Lauro de Souza Lima (ILSL) - Bauru (SP), Brazil.

(C)2012 by Anais Brasileiros de Dermatologia
} 
present article presents a case of relapse with isolated neural manifestation in multibacillary patient, previously treated with multidrug therapy for multibacillary leprosy 24 doses (MDTMB). A literature review was made of the etiological, clinical, propedeutical and diagnostic aspects of this poorly understood situation.

\section{CASE REPORT}

A 44-year-old male patient from the state of Mato Grosso do Sul (MS) reported a previous treatment for dimorphous leprosy with MDTMB 24 doses, between 2001 and 2003. As of the eighteenth dose, the disease progressed with ulnar, tibial and fibular neuritis and prednisone was prescribed. He used the medication intermittently for years, sometimes under medical supervision, sometimes independently, due to the pains. In 2007 , he underwent surgery for decompression of the posterior tibial and fibular nerves, although there was no improvement.

In 2009, the patient looked for the National Referral Center and was hospitalized, with the hypotheses of relapsed leprosy or reinfection, late reactional neuritis, or neuropathy by demyelination. As regards family history, he mentioned that his wife and one of the children were treated by MDTMB. On this occasion, bacilloscopy of index points was negative, and two biopsies of old hypochromic lesions in the right thigh and leg revealed intact nerve branches and negative bacilloscopy. Anti-PGL-1 serology was weakly positive $(0.187$; cutoff $=0.150)$ and Mitsuda test was negative $(3.5 \mathrm{~mm})$. The electroneuromyography (ENMG) showed multiple, mixed, axonal and demyelinizing mononeuropathy with no signs of recent demyelinization. Based on the results of these tests, the patient was discharged from the hospital and to neuropathy follow-up, with prescription of amitriptyline and chlorpromazine for pain management.

In 2010 , the patient returned with exacerbation of the neurological picture, despite the medication. He was hospitalized again and the treatment with prednisone $80 \mathrm{mg} / \mathrm{day}$ and pregabalin $300 \mathrm{mg} /$ day. A new bacilloscopy of index points demonstrated positivity $1+$ on the right elbow, with $0 \%$ morphological index. Anti-PGL1 serology presented greater positivity (0.362) and when those who had contact with the patients were reevaluated, it was found that they were asymptomatic and without any signs of disease activity. The sensitive-motor test detected some points of worsening in comparison to previous ones and ENMG demonstrated reduction in the motor conduction velocity of the right ulnar nerve, although not concluding as a recent disease (Figures 1 and 2).

Forty days later, the patient persisted with complaints of pain, despite the medication taken. It was

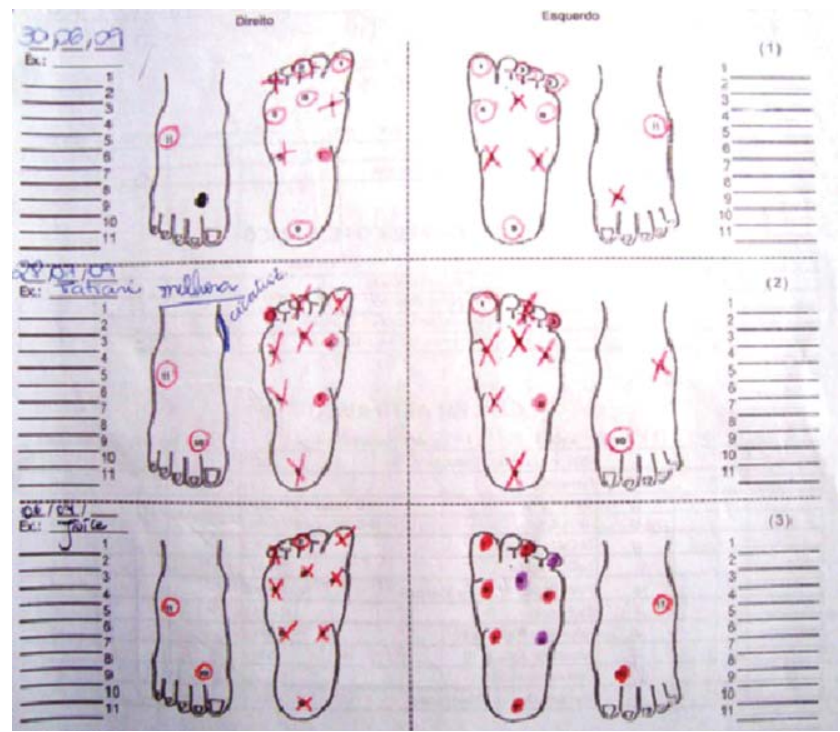

FIGURE 1: Foot sensitivity test on three occasions: (30/JUN/2009), (28/JUL/2009) and (06/APR/2010). Loss of protective sensitivity on both feet.

decided to perform a biopsy of the superficial dorsal branch of the right ulnar nerve, which revealed bacilloscopy $2+$, with fragments within neural branches (Figures 3 and 4). MDTMB was reinstated with gradual reduction of prednisone, which brought improvement of the clinical picture.

\section{DISCUSSION}

The distinction between relapse and reaction is sometimes difficult and mainly based on clinical aspects: skin lesions related to reactions normally have their onset before, during or up to the first year after MDT; the lesions suggestive of relapse, in con-

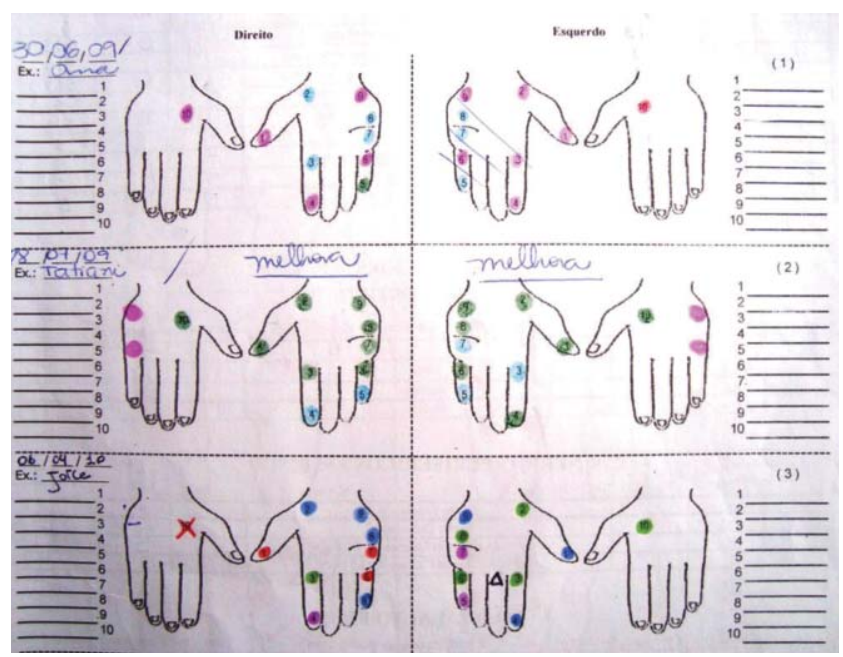

FIgURE 2: Hand sensitivity test on three occasions. Worsening of sensitivity evaluation in the last test 


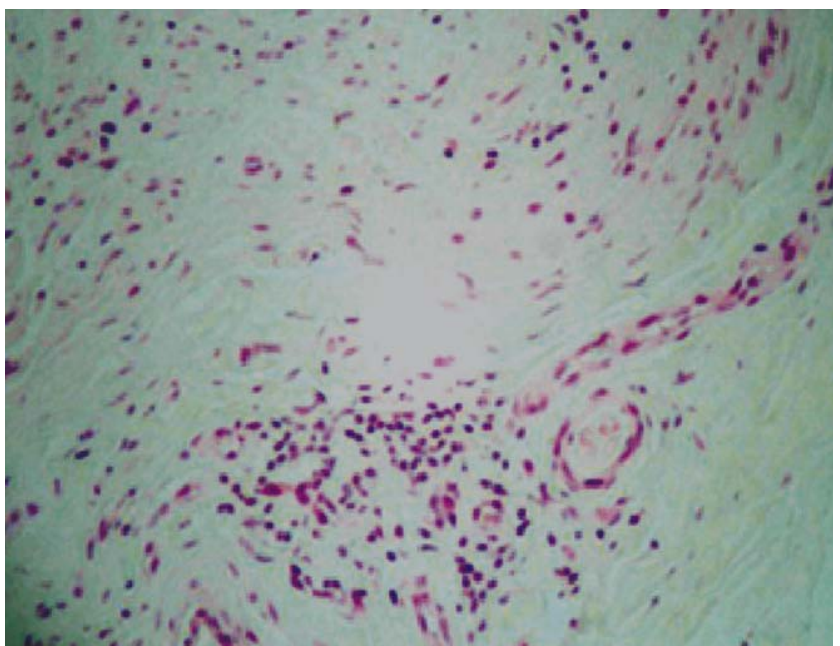

FiguRE 3: Histopathological exam: HE 100x. Biopsy of ulnar nerve: perineural chronic inflammatory infiltrate

trast, have a later onset, several years after the treatment. ${ }^{1}$ The lesions observed in reactional episodes occur suddenly; they are usually multiple, erythematous, infiltrated and, sometimes, ulcerated, and may be accompanied by fever and malaise, and desquamation is common after regression. In contrast with relapse lesions, response to corticoids is pronounced in reactional cases. ${ }^{1}$ In the case at hand, the patient presented a neurological case that did not respond to the habitual therapy of leprosy reactions, suggesting a relapse.

The following factors are related to relapse in leprosy: immunosuppression, bacilli persistence, drug resistance, inadequate or irregular therapy, or classification error ${ }^{3,4}$ The patient presented negative Mitsuda test (smaller than $5 \mathrm{~mm}$ ), which demonstrated a low immune cellular response to Mycobacterium leprae. The Mitsuda test negativity is implied in the greater relapse risk in multibacillary patients, in several studies. ${ }^{5,6}$ There are also other factors associated with greater chance of relapse, such as the presence of several reactional episodes during treatment and the use of corticoids, which was found in this case.

The clinical and histopathological evaluation did not show any signs of relapse of the cutaneous disease; however, the patient had anti-PGL1 serology still positive, and rising. Considering that the PGL-1 is a specific antigen of $M$. Leprae, the presence of rising serological levels of IgM indicates recent contact with the bacillus; therefore, it became imperative to exclu-

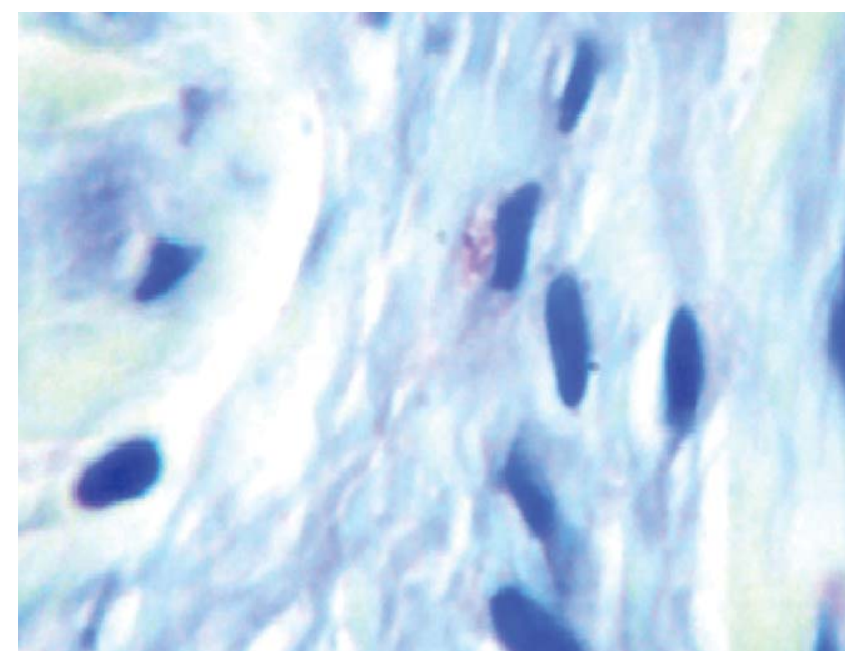

Figure 4: Histopathological exam: Faraco. Biopsy of ulnar nerve: little stained fragmented bacilli within Schwann cells

de active disease or those who were ill and had contact with the patients, but they were asymptomatic and without any signs of the disease, consequently the reinfection hypothesis was discarded. ${ }^{8}$ Thus clinical reasoning pointed toward a case of reactivated disease.

The patient complained of pain on palpation of several nerves, which would represent a clinical signal of essentially neurological disease, since after the use of corticoids and drugs for treatment of neuropathy for 40 days, no clinical or control ENMG had been achieved. Therefore, the neural relapse hypothesis was considered, instead of reactional neuritis. In order to add one more histopathological relapse criterion, it was decided for neural biopsy. Isolatedly, a relapse is considered when a bacilloscopic rate higher or equal to $2+$ in relation to a previous index is found. Even in a patient with Virchowian leprosy, there is a drop in biopsy bacilloscopy, between 0.5 and $1+$ per year.' The neural biopsy revealed $2+$ bacilli 7 years after after discharge, which together with the serology increase is compatible with neural relapse of Hansen's disease.

Thus it was considered a relapse with only neural manifestation in multibacillary patient, previously treated with multidrug therapy 24 doses (MDTMB). The biopsy, an essential tool in neural forms and to evaluate the effectiveness of the treatment in the proposed case, was decisive for the relapse diagnosis and to resume the treatment, which also corroborated the hypothesis of relapse due to the good evolution of the clinical picture and resolution of the case. ${ }^{10} \square$ 


\section{REFERENCES}

1. Ministério da Saúde. Secretaria de Vigilância em Saúde 2010. [acesso 10 Dez. 2010]. Disponível em: http://portal.saude.gov.br/portal/arquivos/pdf/portaria_n_3125_hanseníase_2010.pdf.

2. Bernardi $\bar{C} \overline{D V}$, Gerbase AC, Ferreia J, Pino GD, Bakos L. Operational classification in Hansen's Disease control. Int J Lepr. 1984;52:741.

3. Oliveira MLW. A cura da Hanseniase X magnitude das recidivas. An Bras Dermatol. 1997:72:63-9.

4. Barreto JA, Goya F, Miranda RMC. Hanseníase dimorfa reativada: recidiva ou tratamento insuficiente em paciente imunologicamente suscetível? Hansen Int. 2006;31:35-8.

5. Jesudasan $\mathrm{K}$, Christian M, Bradley D. Relapse rates among non-lepromatous patients released from control. Int J Lepr Other Mycobact Dis. 1984;52:304-10.

6. Diniz LM, Moreira MV, Puppin MA, Oliveira MLWDR. Estudo retrospectivo de recidiva da hanseníase no Estado do Espírito Santo. Rev Soc Bras Med Trop. 2009;42:420-4

7. Brito MFM, Ximenes RAA, Gallo MEN. 0 retratamento por recidiva em hanseníase. An Bras Dermatol. 2005;80:255-60.

8. Moura RS, Calado KL, Oliveira MLW, Buhrer-Sékula S. Leprosy serology using PGL-I: a systematic review. Rev Soc Bras Med Trop. 2008;41(Suppl 2): 11-8.

9. Roche PW, Britton WJ, Failbus SS, Neupane KD, Theuvenet WJ. Serological monitoring of the response to chemotherapy in leprosy patients. Int J Lepr Other Mycobact Dis. 1993;61:35-43.

10. Chimelli L. Valor da biópsia de nervo no diagnóstico da hanseníase: auxilio à clínica nos casos de forma neural pura e reativação. Hansen Int. 1998;89-92.
MAILING ADDRESS:

Leandra Oliveira Teixeira

Instituto Lauro de Souza Lima

Rodovia Comandante João Ribeiro de Barros,

km 225/226

CX POSTAL 3021

17039-800 Bauru, SP

E-mail: oliteixeira@yaboo.com.br

How to cite this article: Teixeira LO, Silva CMGCH, Akamatsu HT, Barreto JA, Soares CT. Neural relapse in multibacillary leprosy 6 years after end of treatment. An Bras Dermatol. 2012;87(2):305-8. 